\title{
Implementasi Function Point Analysis Untuk Pengukuran Kualitas Situs (Studi Kasus: Alibaba.com)
}

\author{
Soetam Rizky Wicaksono ${ }^{1 *}$, Pandyawan Kusumo Kresno Putro ${ }^{2}$, Gracecilla Aprillia Immanuel ${ }^{3}$ \\ 1,2,3 Program Studi Sistem Informasi, Fakultas Sains dan Teknologi, Universitas Ma Chung, Indonesia \\ ${ }^{1,2,3}$ Villa Puncak Tidar N-01, Kota Malang, 65151, Indonesia \\ email: ${ }^{1}$ soetam.rizky@ machung.ac.id, ${ }^{2} 321610010 @$ student.machung.ac.id, ${ }^{3} 321610009 @$ student.machung.ac.id \\ Copyright $\odot 2019$, Politeknik Harapan Bersama, Tegal
}

\begin{abstract}
To find out about how complex and useful a software is, a measurement needs to be done toward the software itself to found its complexity and its usefulness. From few methods that used for measuring a software, Function Point Analysis is most popular method to do the measurement, which measures a software from its functionality. From this research, three factors that very decisive were calculated, those are Crude Function Points (CFP), Relative Complexity Adjustment Factor (RCAF), and the Function Point (FP) calculation itself. This software measurement marks its end of the research at the point of doing a single transaction with the application. The results that came out with the calculation are Crude Function Points (CFP) with 183, Relative Complexity Adjustment Factor (RCAF) with 31, and the Function Point (FP) itself with 175.86, which shows that this web-based application is quite complex.
\end{abstract}

Abstrak - Untuk mengetahui seberapa kompleks dan berguna sebuah perangkat lunak perlu dilakukan pengukuran perangkat lunak untuk menemukan tingkat kompleksitas dan tingkat kegunaan dari perangkat lunak tertentu yang ingin diketahui. Beberapa metode yang berguna untuk mengukur perangkat lunak, salah satu metode yang paling populer untuk digunakan mengukur adalah metode Function Point Analysis, yang mengukur perangkat lunak dari segi fungsionalitas. Di dalam penelitian menggunakan metode Function Point Analysis ini, dilakukan perhitungan terhadap tiga buah faktor yang sangat menentukan, yaitu yang pertama adalah Crude Function Points (CFP), berikutnya yang kedua adalah Relative Complexity Adjustment Factor (RCAF), dan yang terakhir adalah dari function point (FP) itu sendiri. Pengukuran aplikasi website Alibaba ini berhenti hingga hanya batas melakukan satu buah transaksi saja. Hasil yang muncul setelah dilakukan perhitungan didapati nilai hitungan pertama, yaitu nilai Crude Function Points (CFP) sebesar 183, kemudian perhitungan selanjutnya yaitu menghitung Relative Complexity Adjustment Factor (RCAF) yang membuahkan hasil sebesar 31, dan yang terakhir dari Function Point itu sendiri sebesar 175.86 yang menunjukkan bahwa aplikasi berbasis web tersebut cukup kompleks.

Kata Kunci - Kualitas Perangkat Lunak, Function Point Analysis, Alibaba.

*) penulis korespondensi: Soetam Rizky Wicaksono

Email: soetam.rizky@machung.ac.id

\section{PENDAHULUAN}

Bisnis online Alibaba yang berdiri pada tahun 1998 awalnya merupakan perusahaan yang menyediakan layanan dalam proses perdagangan untuk mengunggah, menjual, dan membeli. Hingga akhirnya pada tahun 1999, pendiri Alibaba membentuk perusahaan induk dengan nama "Alibaba Group" dan meresmikan situs website-nya untuk melayani jual-beli di pasar daratan China. Perusahaan online retailer Alibaba yang memiliki alamat situs Alibaba.com ini merupakan salah satu perusahaan online retailer terbesar di dunia, bahkan pada bulan Februari 2018, Alibaba merupakan perusahaan online retailer terbesar nomor 3 di dunia setelah Amazon dan Jingdong [1].

Alibaba termasuk sudah lama dalam bermain di dunia online retailer yaitu sejak pertama kali didirikan tahun 1999 oleh Ma Yun atau yang biasa dikenal dengan nama lain Jack Ma, dari kuartal pertama tahun 2018 sampai kuartal kedua tahun 2018 saja, Alibaba sudah mencatat transaksi jual-beli sebanyak 24 juta transaksi jual-beli dengan total penjualan jika dilihat dari kuartal kedua tahun 2013 hingga kuartal kedua tahun 2018 atau dalam jangka waktu 5 tahun, Alibaba telah mencatat sebanyak 576 juta transaksi penjualan (" Alibaba: cumulative active online buyers 2018 | Statistic," n.d.), hal ini menunjukkan bahwa Alibaba tidak dapat diremehkan dalam dunia online retailer dan tidak kalah saing dengan para rivalnya, seperti ebay dan Amazon. Aktivitas Alibaba di Indonesia sendiri sudah dapat dilihat secara jelas, terbukti dengan Alibaba menyediakan fitur Bahasa Indonesia pada website Alibaba.com untuk para user dari Indonesia, kemudian pada website online retailer itu pula sudah disediakan pilihan mata uang rupiah sebagai label harga dari barang-barang yang dijual.

Penelitian terhadap Alibaba.com dibatasi hingga transaksi pembelian salah satu produk yang dijual pada situs Alibaba.com, hal itu dilakukan karena sebagian besar pengguna mendaftar sebagai member dari situs tersebut untuk membeli produk yang terdapat di Alibaba.com. Metode pengukuran yang diterapkan adalah metode function point untuk mengukur fungsi-fungsi dan fitur-fitur yang dimiliki oleh situs Alibaba.com.

Berdasarkan data dan penjelasan yang telah disampaikan, pengukuran ini membahas mengenai value dari situs Alibaba.com yang mana situs ini dipakai oleh seluruh pengguna di dunia, salah satunya yang termasuk adalah 
Indonesia. Di Indonesia sendiri tidak semua masyarakatnya mengenal teknologi, oleh karena itu dengan dilakukannya pengukuran ini juga dapat mengukur bagaimana tingkat kemudahan dalam mengakses situs ini bagi individu yang asing terhadap teknologi. Untuk tindak lanjut dari penelitian ini tidak digunakan untuk melakukan perbandingan dengan situs-situs yang memiliki kegunaan atau fitur yang sama.

Hingga saat ini Alibaba terkenal kuat dengan semua bisnis e-commerce nya, mulai dari business-to-business (B2B), business-to-customer (B2C), hingga customer-to-customer (C2C). Perusahaan yang dipimpin oleh Jack Ma ini mempunyai enam produk unggulan dalam bidang e-commerce, yaitu Alibaba.com, 1688.com, Taobao.com, Tmall.com, AliExpress.com, juhuasuan.com. Tetapi untuk saat ini yang digunakan untuk penelitian pengukuran adalah online retailer dengan alamat URL Alibaba.com.

Pada penelitian ini digunakan function point analysis (FPA) untuk mengukur website dengan alamat URL Alibaba.com. Hal ini dilakukan karena FPA memiliki beberapa keuntungan, seperti untuk Project Scoping, membuat penyampaian scope dari aplikasi yang diukur oleh peneliti dengan membandingkan functional-functional area yang ada pada aplikasi Keuntungan berikutnya yang didapatkan dari penggunaan FPA adalah apabila software digunakan untuk menggantikan software yang saat ini sedang berjalan, proses bisnis dapat dinilai dan dibandingkan antara kedua software yang telah dibandingkan [3]-[5].

Function Point Analysis juga telah diuji secara empiris menunjukkan hasil yang akurat jika dibandingkan dengan penelitian sebelumnya, hal ini ditunjukkan dengan sesuainya hasil estimasi dengan ukuran aslinya setelah proses pengembangan, dan metode yang memerlukan penilaian khusus dari profesional serta melibatkan pengukuran subjektif. Selanjutnya nilai yang diperoleh dapat digunakan untuk beberapa pengukuran lainnya, misalkan biaya dan waktu yang diperlukan agar dapat membangun perangkat lunak tersebut [6], [7].

\section{LANDASAN TEORI}

Function point merupakan salah satu metode pengukuran dari suatu benda atau dalam hal ini merupakan perangkat lunak (software) lebih spesifik lagi hal yang diukur dan menjadi hasil dari pengukuran tersebut adalah ukuran fungsionalitas. Function point pada awalnya dikembangkan Allan Albrecht di tahun 1979. Function point diciptakan oleh Allan Albrecht sebagai upaya untuk mempermudah orang awam yang tidak mengerti hal teknis dari proyek perangkat lunak untuk mengerti ukuran untuk sebuah perangkat lunak [8].

Untuk menghitung function point dari suatu perangkat lunak ada 5 buah komponen yang harus diperhatikan, dan dari lima buah komponen tersebut dibagi menjadi tiga transaction types dan dua data functions, yaitu; (1) Internal Logical File (ILF), (2) External Interface File (EIF), (3) External Inputs (EI), (4) External Outputs (EO), dan (5) External Inquiry (EQ). Pengertian dari seluruh komponen tersebut adalah sebagai berikut, pertama Internal Logical File (ILF), merupakan logika data yang disimpan dan dimaintain pada aplikasi boundary. Kedua adalah External Interface File (EIF), yakni pengelompokan logika data di luar aplikasi namun menyediakan data yang bisa digunakan pada perangkat lunak. EIF sama dengan ILF tetapi ILF bisa berada pada perangkat lunak lainnya sehingga disebut EIF. Ketiga yaitu External Inputs (EI), yaitu proses data EI atau kendali informasi yang berasal bukan dari application boundary. EI juga bisa menjadi kegiatan unit terkecil dari sebuah perangkat lunak. Pada implementasi EI berupa field - field pada aplikasi. Keempat adalah External Outputs (EO), merupakan proses dasar data melintasi boundary dari dalam aplikasi ke luar aplikasi. EO dapat memperbaharui ILF. Penerapan EO bisa berbentuk laporan yang dicetak. Dan yang terakhir atau kelima yaitu External Inquiry (EQ), merupakan proses fundamental yang terdiri dari gabungan input-output untuk menghasilkan data kembalian (retrieve) atau data agar mampu ditampilkan [9].

Pengukuran adalah aktifitas yang menunjukkan hasil kuantitatif atau berupa numerik dari luasan, jumlah, dimensi, kapasitas, atau atribut yang dihasilkan oleh proses atau produk. Pengukuran dapat digolongkan menjadi 2 cara yakni pengukuran langsung dan pengukuran tidak langsung [10].

Pengukuran langsung pada perangkat lunak membahas tentang biaya dan usaha yang dibutuhkan dalam membangun suatu perangkat lunak. Contoh pengukuran langsung diantaranya pengukuran jumlah baris kode, fungsi, kecepatan eksekusi, ukuran memori, dokumentasi, jumlah masukan, keluaran, dan error dalam satuan tertentu [11].

Contoh dari pengukuran tidak langsung pada perangkat lunak adalah pengukuran kualitas. Sedangkan fungsionalitas, efisiensi, serta reliabilitas, dan kemampuan pemeliharaan merupakan atribut kualitas lainnya dari perangkat lunak yang pengukurannya dilakukan secara tidak langsung [10].

Pengukuran dapat dilakukan saat pengumpulan data mulai dilakukan. Ukuran secara kuantitatif berdasarkan tingkatan pada atribut obyek, sistem atau proses dinyatakan sebagai metrik. Untuk dapat mengukur kualitas perangkat lunak, metrik-metrik harus dikumpulkan untuk mendapatkan indikator. Indikator dari sebuah metrik atau kombinasi dari beberapa jenis metrik dapat menjadi informasi secara lengkap untuk produk tertentu. Informasi yang didapatkan dari indikator tersebut diharapkan bisa membantu pihak manajemen dalam menetapkan kendali sebuah proses untuk pembuatan produk [12].

Menurut Crosby (1979:34) kualitas atau mutu dapat didefinisikan sebagai "conformance to requirements". Ini berarti bahwa selama seseorang bisa berdebat tentang perbedaan antara kebutuhan, keinginan dan kemauannya, maka definisi dari kualitas wajib memahami perspektif pemakai atau konsumen dari sebuah produk, sehingga dalam kasus ini kunci utamanya adalah siapa pengguna dari perangkat lunak tersebut [13].

Karena beragamnya sudut pandang untuk mendefinisikan kualitas, dibutuhkan satu definisi yang disepakati bersama untuk menilai kualitas suatu produk. Berikut adalah definisi kualitas yang dikeluarkan oleh ISO yang dapat dijadikan acuan dalam memandang kualitas sebuah produk. Jadi menurut ISO 9000 (2005), "Kualitas adalah derajat (tingkat) kesesuaian karakteristik suatu produk untuk memenuhi kebutuhan atau spesifikasi yang sudah ditetapkan sebelumnya." [14]. 


\section{PEMBAHASAN}

Pada penelitian terhadap software berbasis web Alibaba.com ditentukan tahapan-tahapan yang digunakan untuk mengukur kualitas dari software atau perangkat lunak. Setelah dilakukan pengamatan pada jurnal lainnya seperti, Kusrini \& Yogyakarta, 2015; Metode, Metrik, Studi, Informatika, \& Sains, 2013; Pratiwi, 2013; Rachmat \& Kunci, 2017 yang juga menggunakan Function Point untuk mengukur perangkat lunak.

Ada tiga tahapan yang harus dilakukan untuk mengukur perangkat lunak, yaitu (1) Mengalkulasi adalah untuk menghitung bobot nilai dari komponen-komponen Function Point yang dikaitkan dengan software yang akan dibuat, atau yang biasa disebut dengan Crude Function Points (CFP); (2) Menghitung Relative Complexity Adjustment Factor (RCAF) atau dalam Bahasa Indonesia dinamakan Faktor Penyesuaian Kompleksitas Relatif; (3) Setelah dilakukan penghitungan terhadap CFP dan RCAF baru bisa dilakukan penghitungan terhadap Function Point (FP) dengan rumus:

$$
F P=C F P *(0.65+0.01 * R C A F)
$$

\section{A. Tahapan 1 (Menghitung CFP)}

Komponen yang harus dihitung dalam CFP adalah jumlah input application, jumlah output application, jumlah online query, logic file, dan jumlah external interface. (1) Jumlah Input Application = 10, apa saja: login, input keterangan profil, memilih barang, mengisi keterangan barang, memasukkan harga yang ditawarkan, memasukkan quantity, konfirmasi order, memasukkan metode pembayaran, memasukkan metode pengiriman, logout; (2) Jumlah Output Application = 2, apa saja: invoice pembelian, invoice konfirmasi pembayaran; (3) Jumlah Online Query $=10$, apa saja: menampilkan barang berdasarkan kategori, menampilkan hasil search barang, menampilkan pilihan bahasa yang ada, verifikasi username, verifikasi password, menyimpan hasil pemilihan barang yang akan dibeli, menyimpan transaksi yang terjadi, menyimpan daftar akun yang register, menyimpan daftar akun yang deactivate account, menyimpan account yang di banned; (4) Jumlah Logic File = 8, apa saja: barang atau produk, seller, user dan password, kota asal, bahasa, metode pembayaran, warna, metode pengiriman; (5) Jumlah External Interface $=2$, apa saja: Data credit card pelanggan, data debit card pelanggan.

TABEL I

PERHITUNGAN CFP

\begin{tabular}{|c|c|c|c|c|c|c|c|c|c|c|}
\hline \multirow{3}{*}{ 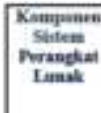 } & \multicolumn{9}{|c|}{ Ninglint Kompletizas } & \multirow{3}{*}{$\begin{array}{l}\text { Tats } \\
\text { CकT }\end{array}$} \\
\hline & \multicolumn{3}{|c|}{ Low } & \multicolumn{3}{|c|}{ Madian } & \multicolumn{3}{|c|}{1150} & \\
\hline & Corin & $\begin{array}{l}\text { Whaphem } \\
\text { fintax }\end{array}$ & Peint & Coum & 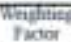 & Phint & Count & 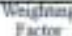 & Paim & \\
\hline & $\pi$ & B & जबना & D & $E$ & FDSP: & 0 & H & म्वरा & Dिल- \\
\hline 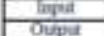 & $\frac{7}{2}$ & $\frac{3}{4}$ & 21 & 2 & $\frac{1}{3}$ & 1 & 1 & T & 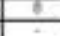 & $\frac{31}{8}$ \\
\hline Oither & $*$ & 3 & 23 & 1 & 4 & 4 & : & 6 & 6 & 34 \\
\hline एoming & 2 & 7 & $T H$ & $T$ & To & पs & $T$ & II & 25 & III \\
\hline 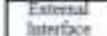 & $\theta$ & 6 & $=$ & 1 & 7 & 7 & 1 & 10 & 10 & 17 \\
\hline ज्ञात & & & & & & & & & & $\sqrt{17}$ \\
\hline
\end{tabular}

Pada Tabel I Nilai 183 merupakan jumlah total hasil pembobotan dari komponen fungsional yang diidentifikasi dan dilakukan perhitungan dengan kompleksitas yang didapat pada website Alibaba. Dari lima komponen yang digunakan untuk perhitungan CFP, input dan online query menjadi yang paling banyak muncul pada kategori kompleksitas rendah sekaligus yang paling penting, karena perangkat lunak ini digunakan untuk transaksi jual beli dan harus memiliki inputan yang mudah bagi user, serta query online yang mudah digunakan oleh user secara umum.

\section{B. Tahapan 2 (Menghitung RCAF)}

RCAF memiliki kegunaan melakukan kalkulasi kesimpulan kompleksitas dari sistem perangkat lunak dari beberapa subyek karakteristik. Penilaian RCAF memiliki skala 0 hingga 5 yang diberikan pada subyek yang diasumsikan memiliki pengaruh terbesar terhadap proses pengembangan perangkat lunak.

TABEL II

PERHITUNGAN RCAF

\begin{tabular}{|l|l|l|l|l|l|l|l|}
\hline No. Subject & \multicolumn{5}{|c|}{ Value } \\
\hline 1 & Tingkat kompleksitas kehandalan backup/recovery & 0 & 1 & 2 & 3 & 4 & 5 \\
\hline 2 & Tingkat kompleksitas komunikasi data & 0 & 1 & 2 & 3 & 4 & 5 \\
\hline 3 & Tingkat kompleksitas pemrosesan terdistribusi & 0 & 1 & 2 & 3 & 4 & 5 \\
\hline 4 & Tingkat kompleksitas kebutuhan akan kinerja & 0 & 1 & 2 & 3 & 4 & 5 \\
\hline 5 & Tingkat kebutuhan lingkungan operasional & & & & & & \\
\hline 6 & Tingkat kebutuhan knowledge pengembang & 0 & 1 & 2 & 3 & 4 & 5 \\
\hline 7 & Tingkat kompleksitas updating file master & 0 & 1 & 2 & 3 & 4 & 5 \\
\hline 8 & Tingkat kompleksitas instalasi & 0 & 1 & 2 & 3 & 4 & 5 \\
\hline 9 & Tingkat kompleksitas aplikasi input, output, query online dan file & 0 & 1 & 2 & 3 & 4 & 5 \\
\hline 10 & Tingkat kompleksitas pemrosesan data & 0 & 1 & 2 & 3 & 4 & 5 \\
\hline 11 & Tingkat tidak memungkinkan penggunaan kembali dari kode (reuse) & 0 & 1 & 2 & 3 & 4 & 5 \\
\hline 12 & Tingkat variasi organisasi pelanggan & 0 & 1 & 2 & 3 & 4 & 5 \\
\hline 13 & Tingkat kemungkinan perubahan/fleksibilitas & 0 & 2 & 3 & 4 & 5 \\
\hline 14 & Tingkat kebutuhan kemudahan penggunaan & 0 & 1 & 2 & 3 & 4 & 5 \\
\hline & Total RCAF & & 31 & \\
\hline
\end{tabular}

Pada Tabel II Kategori ekstrem (value 0 dan 5) ada tiga pada perhitungan RCAF; (1) Tingkat kompleksitas updating file master memiliki nilai 5 karena apabila dilakukan update file master pada database aplikasi merupakan hal yang kompleks, (2) Tingkat kompleksitas pada saat proses instalasi perangkat lunak memiliki nilai 0 disebabkan perangkat lunak tersebut tidak membutuhkan instalasi karena aplikasi berbasis web, dan (3) Tingkat kebutuhan kemudahan penggunaan mendapat nilai 5 karena memang aplikasi cukup mudah untuk digunakan.

Lalu ada tiga pula titik fokus/faktor (yang paling penting) pada perhitungan RCAF; (1) Tingkat kompleksitas instalasi penting karena penggunaan aplikasi cenderung diawali dengan instalasi, (2) Tingkat kompleksitas perangkat lunak dari segi input, output, query online dan file penting karena aplikasi yang dibahas merupakan aplikasi yang banyak menggunakan inputan dan menghasilkan inputan, dan (3) Tingkat kebutuhan lingkungan operasional penting karena tidak membutuhkan perangkat yang high-end. 


\section{Tahapan 3 (Menghitung FP)}

Setelah menghitung CFP dan RCAF dari perangkat lunak tersebut baru bisa dilakukan penghitungan Function Point (FP) dari perangkat lunak, dengan menggunakan rumus (1) Berarti, bila total dari CFP dan total dari RCAF dimasukkan ke dalam rumus perhitungannya akan menjadi seperti ini:

$$
\begin{aligned}
& \mathrm{FP}=183 *(0.65+0.01 * 31) \\
& \mathrm{FP}=183 *(0.65+0.31) \\
& \mathrm{FP}=183 *(0.96) \\
& \underline{\mathrm{FP}}=175.86
\end{aligned}
$$

\section{Hasil}

Setelah dilakukan perhitungan CFP, RCAF, dan FP ditemukan hasil secara berturut-turut dengan besaran 183, 31, dan 175.86, oleh karena itu dapat disimpulkan bahwa aplikasi ini merupakan aplikasi yang cukup kompleks, karena semakin besar angka FP, maka aplikasi otomatis merupakan aplikasi yang lebih kompleks dari angka di bawahnya.

\section{SIMPULAN}

Dari penelitian ini dapat disimpulkan beberapa hal, yaitu Dengan menggunakan Function Point Analysis sebuah aplikasi atau perangkat lunak bisa diukur, mulai dari kegunaan dan fungsinya hingga tingkat kompleksitas perangkat lunak. Hasil berikutnya adalah aplikasi berbasis web ini merupakan aplikasi yang kompleks, karena hanya dibatasi sampai transaksi satu jenis barang saja nilai dari Function Point sudah menyentuh angka 175.86. dan hasil kesimpulan yang terakhir adalah penghitungan Function Point pada aplikasi cenderung subyektif, sehingga membutuhkan tenaga yang ahli dalam melakukannya

\section{DAFTAR PUSTAKA}

[1] "8 Largest E-Commerce Companies in the World and No, Alibaba is Not the Largest Chinese E-Commerce - AxiomQ Ventures." [Online]. Available: https://axiomq.com/blog/8-largest-e-commerce-companiesin-the-world/. [Accessed: 21-Nov-2018].
[2] “• Alibaba: cumulative active online buyers 2018 | Statistic." [Online]. Available: https://www.statista.com/statistics/226927/alibabacumulative-active-online-buyers-taobao-tmall/. [Accessed: 28-Nov2018].

[3] P. M. Morris and J. M. Desharnais, "Function Point Analysis Validating the Result," Gen. Syst., pp. 1-30, 2001.

[4] C. Symons, "Come back function point analysis (modernized)-all is forgiven!)," Proc. 4th Eur. Conf. Softw., pp. 1-12, 2001.

[5] D. Longstreet, "Fundamentals of Function Point Analysis," Softw. Dev. Mag., pp. 1-9, 2005.

[6] N. Rachmat, "Estimasi Ukuran Perangkat Lunak Menggunakan Function Point Analysis - Studi Kasus Aplikasi Pengujian dan Pembelajaran Berbasis Web," vol. 3, no. 1, 2017.

[7] D. Khairani, "Studi Kasus Pengukuran Sistem Informasi Menggunakan Function Point ( Fp )," vol. 8, no. 2, pp. 1-7, 2015.

[8] A. R. Irawati and K. Mustofa, "Pengukuran Fungsionalitas Perangkat Lunak Menggunakan Metode Function Point Berdasarkan Dokumentasi Desain,” IJCCS (Indonesian J. Comput. Cybern. Syst., vol. 7, no. 2, pp. $111-120,2013$.

[9] F. A. Juyuspan and A. Hidayati, "DALAM PENGEMBANGAN PERANGKAT LUNAK MENGGUNAKAN ANALISA FUNCTION POINT," vol. 5, no. 2, pp. 85-92, 2016.

[10] U. Ibn and K. Bogor, "Pengukuran kualitas perangkat lunak sistem manajemen pelaporan kegiatan berbasis web peringatan berbasis email," no. November, 2017.

[11] Soekirman, "Universitas sumatera utara," balita BGM, no. X, pp. 1-5, 2014.

[12] Ritzkal and M. Subchan, "Manajemen Pelaporan Kegiatan Berbasis Web," vol. 2, no. 2502, 2017.

[13] “KUALITAS PERANGKAT LUNAK: Definisi, Pengukuran dan Implementasi (Studi kasus dalam open-source software)." [Online]. Available: $\quad$ https://iyuadi.wordpress.com/2008/01/08/kualitasperangkat-lunak-definisi-pengukuran-dan-implementasi-studi-kasusdalam-open-source-software/. [Accessed: 28-Nov-2018].

[14] "Nasir Widha's Blog» Kualitas." [Online]. Available: http://nasirwidha.lecture.ub.ac.id/2012/05/kualitas/. [Accessed: 28Nov-2018].

[15] D. Pratiwi, "Implementation of Function Point Analysis in Measuring the Volume Estimation of Software System in Object Oriented and Structural Model of Academic System," vol. 70, no. 10, pp. 1-4, 2013.

[16] K. Kusrini, "Pengukuran Volume Software berdasarkan Kompleksitasnya dengan Metode Function Point Kusrini, Muhammad Dedi Iskandar,” vol. m, no. September, 2015.

[17] K. Metode, P. Metrik, P. Studi, T. Informatika, and F. Sains, "Kajian Metode Perhitungan Metrik Function-Point dan Penerapannya pada Dua Perangkat Lunak yang Dipilih,” vol. 2, no. 1, pp. 28-34, 2013. 